\title{
Measuring quality indicators in the operating room: cleaning and turnover time
}

\author{
Marli de Carvalho Jericó ${ }^{1}$ \\ Márcia Galan Perroca ${ }^{2}$ \\ Vivian Colombo da Penha ${ }^{3}$
}

This exploratory-descriptive study was carried out in the Surgical Center Unit of a university hospital aiming to measure time spent with concurrent cleaning performed by the cleaning service and turnover time and also investigated potential associations between cleaning time and the surgery's magnitude and specialty, period of the day and the room's size. The sample consisted of 101 surgeries, computing cleaning time and 60 surgeries, computing turnover time. The Kaplan-Meier method was used to analyze time and Pearson's correlation to study potential correlations. The time spent in concurrent cleaning was 7.1 minutes and turnover time was 35.6 minutes. No association between cleaning time and the other variables was found. These findings can support nurses in the efficient use of resources thereby speeding up the work process in the operating room.

Descriptors: Operating Room Nursing; Indicators; Management Indicators; Indicators of Health Services; Surgical Procedures, Operative.

\footnotetext{
${ }^{1}$ RN, Ph.D. in Nursing, Professor, Departamento de Enfermagem Especializada, Faculdade de Medicina de São José do Rio Preto, SP, Brazil. E-mail: marli@famerp.br.

${ }^{2}$ RN, Ph.D. in Nursing, Professor Adjunct, Departamento de Enfermagem Especializada, Faculdade de Medicina de São José do Rio Preto, SP, Brazil. E-mail: marcia.perroca@gmail.com.

${ }^{3}$ RN, Hospital de Clinicas de Marília, SP, Brasil. Unidade São Francisco, Associação Beneficente Hospital Universitário, Marília, SP, Brazil. E-mail: riomar.2006@hotmail.com.
}

Corresponding Author: Marli de Carvalho Jericó Av. Bady Bassitt, 4270, Torre 4, Apto 151 CEP: 15025-900, São José do Rio Preto, SP E-mail: marli@famerp.br 


\section{Mensuração de indicadores de qualidade em centro cirúrgico: tempo de limpeza e intervalo entre cirurgias}

Este estudo exploratório-descritivo foi conduzido na unidade de centro cirúrgico de um hospital de ensino, tendo por objetivos: mensurar o tempo despendido para limpeza concorrente pelo Serviço de Higiene e Limpeza, em sala de operação, e o intervalo entre as cirurgias, e investigar a associação entre o tempo de limpeza e porte e especialidade da cirurgia, período de ocorrência e tamanho da sala. A amostra foi constituída por 101 (estudo tempo de limpeza) e 60 cirurgias (estudo intervalo entre cirurgias). 0 método de Kaplan-Meier foi utilizado para análise do tempo e a correlação de Pearson para o estudo das associações. O tempo da limpeza concorrente da sala foi de 7,1 minutos e o do intervalo entre cirurgias de 35,6 minutos. Não se encontrou correlação entre tempo de limpeza e demais variáveis. Esses achados instrumentalizam os enfermeiros no uso eficiente de recursos, agilizando o processo de trabalho em centro cirúrgico.

Descritores: Enfermagem de Centro Cirúrgico; Indicadores; Indicadores de Gestão; Indicadores de Serviços; Procedimentos Cirúrgicos Operatórios.

\section{Mensuración de indicadores de calidad en un centro quirúrgico: tiempo de limpieza e intervalo entre cirugías}

Este estudio exploratorio y descriptivo fue conducido en la Unidad de Centro Quirúrgico de un hospital de enseñanza teniendo por objetivos mensurar el tiempo utilizado para limpieza concurrente en sala de operación (por el Servicio de Higiene y Limpieza) y el intervalo entre las cirugías; e, investigar las asociaciones entre: tiempo de limpieza, porte de la cirugía, especialidad de la cirugía, período de ocurrencia y tamaño de la sala. El estudio fue constituido de 101 casos de limpieza (estudio de tiempo de limpieza) y 60 cirugías (estudio de intervalo entre cirugías). El método de Kaplan-Meier fue utilizado para el análisis del tiempo y la correlación de Pearson para el estudio de las asociaciones. El tiempo promedio de limpieza concurrente de la sala fue de 7,1 minutos y el del intervalo entre cirugías de 35,6 minutos. No fue encontrada correlación entre el tiempo de limpieza y las demás variables. Estos hallazgos instrumentalizan a los enfermeros en el uso eficiente de recursos, agilizando el proceso de trabajo en el Centro Quirúrgico.

Descriptores: Enfermería de Quirófano; Indicadores; Indicadores de Gestión; Indicadores de Servicios; Procedimientos Quirúrgicos Operativos.

\section{Introduction}

Concern with quality in health organizations has been manifested through the search for best practices to meet the demands of a competitive market and clients more aware of their rights. Measuring performance became vital for the improvement of work processes to reduce operational costs and promote the satisfaction of clients. The objects of such measurements includes the necessary structure or what was actually used, the processes and results obtained as well as the influences and repercussions observed in the environment ${ }^{(1)}$; the instruments used are the indicators.
Even though indicators should not be seen as a direct measurement of quality, these can be considered quantitative measures used to re-evaluate, re-plan, and reorganize the activities of a given service, supporting decision-making in the management of care $^{(2)}$. It is

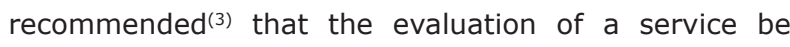
appropriately performed, using a group of indicators, since the use of a single indicator may not represent reality.

The Surgical Center Unit (SCU) is one of the most complex units in a hospital due to its innumerous 
processes and sub-processes directly or indirectly connected to the production of surgeries(4). The construction and monitoring of quality indicators specific to this unit can guide its management process and reveal deviations in quality.

Innumerable indicators, both related to the structure, processes and results( ${ }^{(6)}$, can be used in the surgical unit(5). The average time for cleaning the Operating Room (OR) and the interval between surgeries (turnover) can be classified as indicators of processes because they are related to the activities linked to the infrastructure intended to promote means for core activities $^{(1)}$.

Cleaning the $\mathrm{OR}$ is one of the procedures that controls environmental contamination(7) and it is recommended to do so before, during and after surgery and at the end of the $d_{a y}^{(8)}$. Concurrent cleaning is performed after one surgery and before the beginning of another, involving removing dirty and organic matter from furniture, equipment and surfaces ${ }^{(8)}$. SCU cleaning procedures are usually divided between the staff of the Cleaning Service and the circulating nurse, so that the personnel responsible for cleaning removes dirt from the ceiling, walls and floor and the circulating nurse cleans furniture and equipment.

The interval between surgeries, also referred to as turnover time, can be addressed in different manners according to the perspective of the professionals involved. For nurses, it means the time from when one patient leaves the room until the next patient enters the room and includes time for cleaning the OR and setting up. Anesthesiologists consider turnover time to be the time from when the patient is sent to the post-anesthetic recovery room until the next patient is brought in. And finally, surgeons consider the period to be the time from the closure of a surgical wound until the first incision in a new patient ${ }^{(9)}$. Turnover time includes the cleaning the OR and setting up but not the delay between $\operatorname{cases}^{(10)}$.

The measurement of SCU productivity has received great attention from researchers. Brazilian studies have investigated occupation rate ${ }^{(11)}$, average length of surgeries, satisfactory waiting time between surgeries ${ }^{(12)}$, and the operational capacity of the $\mathrm{SCU}^{(13)}$, analyzing factors that determine a gain or loss of productivity(14-15).

A study conducted in 31 hospitals in the United States analyzed turnover(10) time and the impact of reducing it in personnel costs ${ }^{(16)}$. A score system composed of eight indicators was developed to quantify the performance within the OR and identify areas requiring improvement ${ }^{(17)}$. It contemplates, among others, the indicator 'turnover'.
However, such a system was based on American standards and since it is a conceptual proposition, its efficiency needs to the validated.

Cleaning time has accounted for delay and prolonged turnover ${ }^{(13)}$, often generating complaints and discontent on the part of surgeons. The situation is not different in the studied hospital. The hiring of an outsourced service to clean the SCU required monitoring this performance indicator to verify whether the new personnel met the needs of this unit.

Hence, concern to improve teamwork dynamics and maximize the use of surgical capacity became the focus of this investigation, which had as objectives:

- Measuring the time spent in the operating room by the cleaning service personnel during concurrent cleaning and turnover in the surgical center of a university hospital;

- Investigating potential associations between cleaning time and the surgery's magnitude and specialty, period of occurrence, and size of the operating room.

\section{Method}

This exploratory and descriptive study with quantitative approach was conducted in the SCU of a university school with extra capacity located in the interior of the state of São Paulo, Brazil. This unit is composed of 25 OR with sizes varying from $20 \mathrm{~m}^{2}$ to $42 \mathrm{~m}^{2}$ and a room for transplantations with $62 \mathrm{~m}^{2}$. The surgical center performs 2,177 surgeries a month, resulting in a daily average of minor, medium and major 73 surgeries distributed in 16 surgical specialties. The schedule includes 7am to $7 \mathrm{pm}$ daily from Monday to Friday and Saturdays in the morning. The night shift, weekends and holidays are for emergencies only.

The outsourcing service is composed of one nurse, one supervisor and eight cleaning assistants. The division between the responsibilities of the circulating nurse and the cleaning service personnel concerning the concurrent cleaning procedures followed the standards previously described.

The sample's study was composed of all the surgeries performed between May $19^{\text {th }}$ and $30^{\text {th }}, 2008$. The sample was initially composed of 101 surgeries to compute cleaning time and afterwards another 60 surgeries were considered to evaluate turnover time.

\section{Instrument and Procedure for Data Collection}

A structured instrument was developed to record information concerning direct observation. It was 
composed of items that characterize the surgeries (type, size, specialty, duration, clientele) and time spent during the various phases, from the exit of one patient to the entrance of another in the OR. The classification of surgeries by body areas was performed according to the table of the Brazilian Medical Association(18). The surgical magnitude was determined according to the following concepts $^{(19)}$ : Size I (minor) - surgeries with a duration of up to two hours; Size II (medium) - surgeries with a duration of in average of two to four hours, and Size III (major) surgeries with a duration from four to six hours.

Time was measured with the aid of a stopwatch (with a certified calibration) and recorded in a previously tested form. Interrupted or repetitive reading, in which the stopwatch goes back to zero at the end of each observed period, was performed. Time was measured by one of the researchers helped by three nurses from the SCU who were previously instructed concerning the study, in 24 OR (one OR was excluded due to its location, which was too far from the others) from Monday to Friday in the mornings and afternoons.

Data collection was only initiated after formal authorization was obtained from the institution and the nursing manager of the Surgical Center Unit. The study was exempted from the Ethics Research Committee because it did not fit Resolution 196/96 (protocol No. 008/2011).

\section{Measuring Time}

Time was recorded based on five points in time in accordance with the study of Gatto(14) and based on the study's objectives:

Duration of the anesthetic-surgical procedure: period between the time the patient is positioned for surgery, anesthetized and surgery is initiated up to the end of administering the anesthesia;

Duration post-anesthetic: period from the end of the anesthetic procedure up to when the patient leaves the surgical room;

Duration post cleaning: period from the time the patient leaves the room up to the arrival of the cleaning service personnel;

Cleaning time: time from when the cleaning personnel enters the OR up to the end of the concurrent cleaning; Post cleaning and setting up time: time spent from when the cleaning personnel leaves the OR to when the circulating nurse enters the room and ending when s/he completes setting it up to admit the next patient.

Turnover time took into account the time when one patient left the OR until the next entered the room.

\section{Data analysis}

Data were analyzed statistically through the method of survival analysis using the Kaplan-Meier non-parametric estimator to verify the various periods investigated with a confidence interval of $95 \%$. Survival analysis is a collection of statistical procedures used to analyze data in which the variable of interest is the time until a given event occurs. The event can be death, disease or any experience of interest that happens to an individual(20). Person's coefficient (2-tailed) was employed to study potential associations among the variables (time spent to clean the OR, the surgery's magnitude and specialty, period of occurrence, and size of the room); level of significance was fixed at 0.05 .

Descriptive data are presented in absolute numbers, percentages, Mean Time To Failure (event) (MTTF) and standard error, with a Confidence Interval (CI) of 95\%, and medians and quartiles (Q1 and Q3). The statistical analysis was performed using Minitab Statistical Software (MINITAB) version 12.22 and SPSS version 15.0.

\section{Results}

Most patients undergoing surgery were men $(52.5 \%)$ with an average age of $46.2 \pm 25.4$ years old (variation 1-96) and $83.2 \%$ were users of the Single Health System (SUS).

In relation to the surgical procedures performed (Table 1 ), the results indicate a greater occurrence of surgeries of magnitude I (78-77.2\%), as well as of scheduled surgeries (92-91.1\%) in the following body areas: nose, eyes, ears (20-19.8\%), digestive system and annexes (18-17.8\%), and cardio-circulatory system (13-12.9\%), especially in the morning (68-67.3).

Table 1 - Characterization of surgical procedures $(\mathrm{N}=101)$. São José do Rio Preto, SP, Brazil, 2008

\begin{tabular}{lcc}
\hline \multicolumn{1}{c}{ Characteristics } & N & $\%$ \\
\hline Magnitude & 78 & 77.2 \\
Minor (I) & 17 & 16.9 \\
Medium (II) & 6 & 5.9 \\
Major (II) & & \\
Body areas & 20 & 19.8 \\
Nose, eyes, ears & 18 & 17.8 \\
Digestive system and annexes & 13 & 12.9 \\
Cardio-circulatory system & 11 & 10.9 \\
Chest wall & 10 & 9.9 \\
Skeletal muscle system & 6 & 5.9 \\
Urinary system & &
\end{tabular}

(continue...) 
Table 1 - (continuation)

\begin{tabular}{lcc}
\multicolumn{1}{c}{ Characteristics } & N & \% \\
\hline Skin and subcutaneous tissue & 6 & 5.9 \\
Respiratory system & 5 & 4.9 \\
Genital/repro male system & 4 & 4.0 \\
Genital/repro female system & 4 & 4.0 \\
Others* & 4 & 4.0 \\
Type & & \\
Scheduled surgeries & 92 & 91.1 \\
Non-scheduled surgeries & 9 & 8.9 \\
Period & & \\
Morning & 68 & 67.3 \\
Afternoon & 33 & 32.7 \\
\hline
\end{tabular}

* head, neck and central nervous system (CNS).
Table 2 presents the times measured at five points in time. Mean time to failure, in this case, OR concurrent cleaning was 7.1 minutes (CI 95\%: [6.27.9]) and the turnover time was of 35.6 minutes (CI 95\%: [29.2-42.0]).

The curves of survival constructed through the Kaplan-Meier plan to evaluate the duration of each event, that is, time before cleaning, cleaning time, post cleaning time and setting up, and turnover are presented in Figure 1.

Table 2 - Distribution of measured times in minutes (N=101). São José do Rio Preto, SP, Brazil, 2008

\begin{tabular}{|c|c|c|c|c|}
\hline Measured times & MTTF (SE) & IC $95 \%$ & M & Q1 - Q3 \\
\hline Surgical-anesthetic time & $101.5(8.0)$ & $85.7-117.1$ & 75.0 & $45.0-12.0$ \\
\hline Post anesthesia time & $17.4(1.6)$ & $14.3-20.5$ & 15.0 & $5.0-22.0$ \\
\hline Pre cleaning time & $21.1(2.6)$ & $16.0-26.1$ & 13.0 & $7.0-25.0$ \\
\hline Cleaning time & $7.1(0.4)$ & $6.2-7.9$ & 6.0 & $5.0-8.0$ \\
\hline Post cleaning and setting up $(\mathrm{N}=60)$ & $17.9(2.8)$ & $12.4-23.5$ & 9.0 & $4.0-21.0$ \\
\hline Turnover $(\mathrm{N}=60)$ & 35.6 & $29.2-42.0$ & 27.0 & $17.0-43.0$ \\
\hline
\end{tabular}

* MTTF: Mean Time To Failure (event) (MTTF); SE: Standard Error
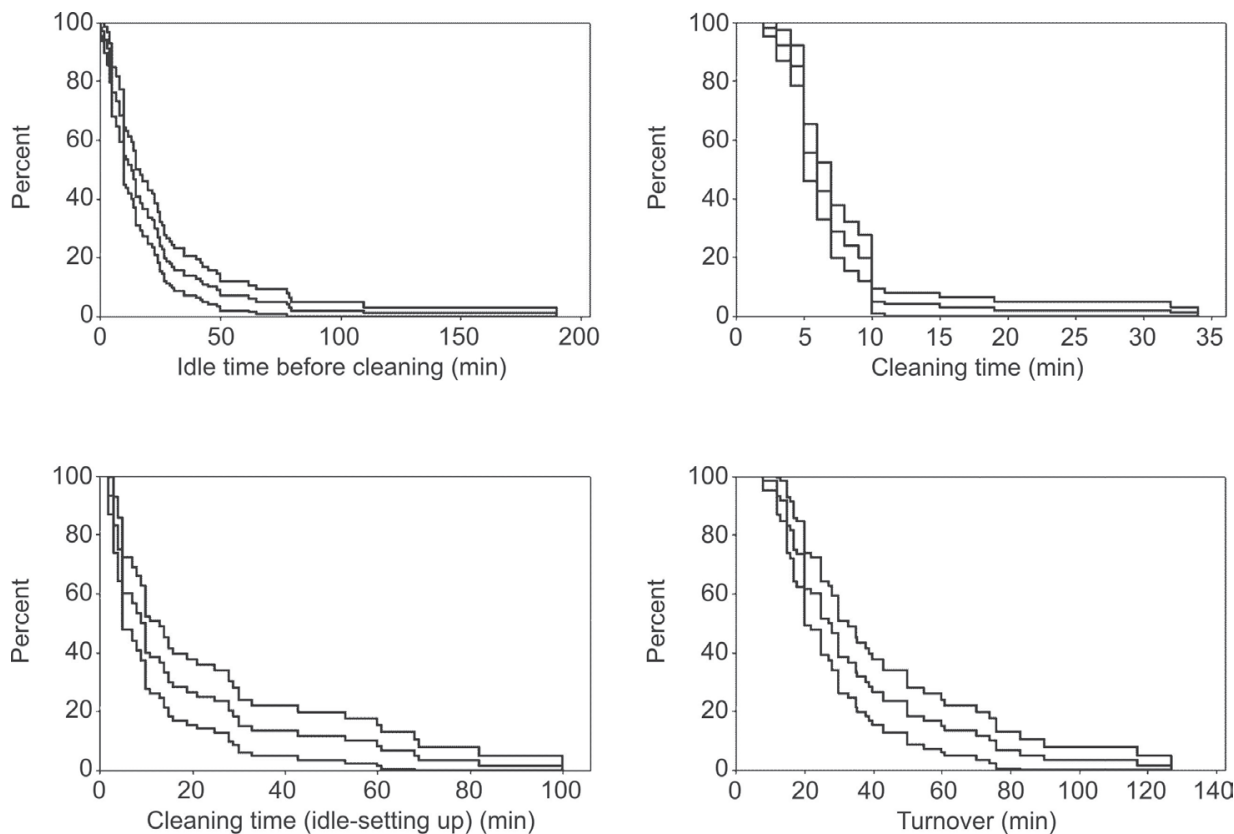

Figure 1- Kaplan-Meier Curves for times prior to OR cleaning, concurrent cleaning, post cleaning and turnover

According to Person's coefficient, no statistically significant association $(p<0.05)$ was found between the OR cleaning time and the variables: size and the surgery magnitude or specialty, period of occurrence, and size of the room.

\section{Discussion}

The variable 'time' was investigated to measure the activities 'OR concurrent cleaning' and 'turnover'. The management of time during work has been considered 
a resource of essential importance in organizations to improve processes and productivity ${ }^{(21)}$. A service is productive when it is capable of rationalizing the use of resources to produce results(22).

Average time of concurrent cleaning was 7.1 minutes computed in a context where most surgeries were minor $(77.2 \%)$, scheduled $(91.1 \%)$, in which the specialties nose, eyes, ears; digestive system and annexes; and cardio-circulatory system jointly accounted for $50.5 \%$ of the surgeries. This result may be considered minor, but it refers only to the cleaning activities performed by the cleaning personnel. In the studied SCU, the OR cleaning procedures performed by the circulating nurse usually precede those of the cleaning personnel. They only work together when there is a need to speed up the process. This flow is usually determined by the surgeon's needs. The results are also evidence that the OR cleaning time spent by the cleaning personnel is not influenced by the surgery's magnitude or period of the day in which the surgery occurs, nor did the size of the room interfere in the cleaning time as previously thought.

The average time elapsed from when one patient leaves the room until the cleaning personnel arrived at the OR (pre cleaning time) was 21.1 minutes. Specific activities were performed in this period by the circulating nurse such as sending the patient to the post anesthetic recovery room, removing contaminated material from the OR and sending it to the Sterilization Material Center and also cleaning furniture and equipment. It is worth noting that the SCU has a large area and its physical area and structure do not make moving around and distributing material easy on the part of the circulating nurse. Even though the post anesthetic recovery room is far away from most ORs, forcing the circulating nurse to walk a certain distance, a sample of 50 surgeries prior to this investigation, indicated that an average time of transportation of about 5 minutes was required.

The two times (cleaning personnel and circulating nurse) totaled approximately 28.8 minutes of cleaning time, excluding the time reserved to set up the OR. One study addressing this topic reports 30 minutes were spent cleaning and setting up the $\mathrm{OR}^{(14)}$. Another study $^{(12)}$ established 20 minutes as the standard cleaning time after a study of historical series of surgeries that occurred in the same room and were performed by the same surgeon.

To measure the dynamics of surgical rooms, some operational indexes have been proposed(14) to determine gain (optimization index) or loss (resistance index) of operational capacity. An investigation involving 1,908 anesthetic-surgical procedures ${ }^{(15)}$ considered the OR cleaning time and setting up one of the variables to determine the optimization index (time $\leq 20$ minutes) and resistance (time $\geq 21$ minutes). It is important to note that these authors consider that the cleaning time and set up begins after the anesthesia, regardless of whether the patient left the OR or not, and not after the circulating nurse, who took the patient from the OR to the post anesthesia room and then returned to the $O R$, as is usually reported in the literature ${ }^{(19)}$. This is evidence ${ }^{(15)}$ that the optimization index was mainly determined by rearranging the rooms $(41.9 \%)$ and cleaning time $\leq$ 20 minutes $(18.1 \%)$. These results emphasize the importance of finding an appropriate cleaning time and setting up to boost SCU productivity.

An aspect of this study that deserves attention is the average time spent after the cleaning personnel leaves the OR and the next patient enters the room (17.9 minutes), which is the time when the OR is being set up. Since the objective of this study was to measure the OR concurrent cleaning time from the perspective of the cleaning personnel, the time spent by the circulating nurses was not measured. Hence, we cannot determine the time used to set up the ORs.

The turnover time identified in the studied SCU was 35.6 minutes, longer than that found in one private hospital(12) (around 20 minutes), though it was computed from the perspective of the surgeon. It is important to keep in mind that OR cleaning in the SCU of this private hospital begins at the end of the patient's anesthesia while s/he is still in the room. Another study(15) using the same criterion reports that a turnover of 20 minutes was achieved in $88.3 \%$ of the studied surgeries.

An American score system ${ }^{(17)}$ developed to quantify performance in surgical facilities classifies turnover time (incoming-outgoing patient) into three categories: poor, time > 40 minutes, medium, from 25 to 40 minutes, and high performance, $<25$ minutes. The time of 36 minutes found in this study would be considered of medium performance according to American standards. Even though this system contains elements applicable to surgical centers in the United States, and therefore should be viewed with caution in relation to facilities in Brazil, it does constitute a parameter given the absence of Brazilian ones. Another study ${ }^{(10)}$ conducted in American SCUs considered a benchmark to be a turnover time below 25 minutes.

The effective use of ORs has been a goal pursued by nurses managing Surgical Centers. Idleness is considered invisible waste but perceived in the results 
of hospital facilities(23). This same author concluded, after investigating the degree of idleness in the surgical centers of four hospitals in the state of Minas Gerais, that it is preferable to implement changes in management, rather than invest in the construction of new ORs.

Appropriate administration of OR cleaning time, setting up, and turnover time are essential factors in the promotion of efficiency in services provided by SCUs. Reducing time required for turnover, OR cleaning and setting up enables a greater number of procedures to be performed in the operating room, increasing the unit's productive capacity. Considering the significant representation of surgical patients in hospital income, the maximum use of surgical capacity favors better management of resources ${ }^{(24)}$.

Hence, the participation of nurse managers is important in the process of quality and productivity evaluation of this unit in order to detect and redesign activities that are not efficient, and continually monitor and compare results with those found in benchmark hospitals.

One of the limitations of this study is that the cleaning time spent by the circulating nurse was not computed, which may have influenced the results. However, given the study's exploratory descriptive nature, it contributes to nursing practice in the field, a topic seldom addressed in Brazilian literature. It is worth noting that it was conducted in a public university hospital and its results reflect the structure and process of work inherent to the studied SCU. Therefore, further studies conducted in different settings are recommended. The use of similar criteria to compute time and the construction of national parameters would promote the comparison of different studies' findings.

\section{Conclusion}

This study presented the dynamics of a surgical center concerning operating room concurrent cleaning and turnover time and the standards of production generated that impact productivity in the studied unit. When these activities are not appropriately structured and monitored there is a loss of operational and financial capacity in health facilities.

The work of nurses managing the evaluation of the work process in this unit and their ability to use information generated by indicators in decision-making is essential to the continuous search for standards of excellence.

\section{References}

1. Bittar OJNV. Indicadores de qualidade e quantidade em saúde. Rev Adm Saúde 2008;10(40):87-93.

2. Bittar OJNV. Indicadores de qualidade e quantidade em saúde - Parte II. Rev Adm Saúde. 2004;6(22):15-8.

3. Malik AM, Schiesari LMC. Qualidade na gestão local de serviços e ações de saúde. São Paulo: Fundação Petrópolis; 1998.

4. Duarte IG, Ferreira DP. Uso de indicadores na gestão de um centro cirúrgico. RAS. 2006; 8(31):63-70.

5. Dib MFF, Silva AF da, Iwamoto VE. Indicadores em CC. In: Leão ER, Silva CPR, Alvarenga DC, Mendonça SHF. Qualidade em Saúde e indicadores como ferramenta de gestão. São Paulo: Edit Yendis; 2008. p. 263-79.

6. Donabedian A. The quality of care: how can it be assessed? JAMA. 1988;260(12):1743-8.

7. Nobre LF, Galvão CM, Graziano KU, Corniani F. Avaliação de indicadores do controle da contaminação ambiental da sala de operação: um estudo piloto. Medicina. (Ribeirão Preto). abr-jun 2001;34:183-93.

8. Sociedade Brasileira de Enfermeiros de Centro Cirúrgico, Recuperação Anestésica e Centro de Material e Esterilização - SOBECC. Praticas recomendadas SOBECC/ Sociedade Brasileira de Enfermeiros de Centro Cirúrgico, Recuperação Anestésica e Centro de Material e Esterilização. 5.ed. São Paulo: SOBECC; 2009. p. 52-5.

9. Surgery Management Improvment Group - SMI Group- [acesso 18 ago 2010]. Disponível em: www. surgerymanagement.com/presentations/rapidopertion-room-turnover1.php.

10. Dexter F, Epstein RH, Marcon E, Ledolter J: Estimating the incidence of prolonged turnover times and delays by time of day. Anesthesiology. 2005;102:1242-8.

11. Strofaro JR. Estudo da taxa de ocupação do centro cirúrgico através da modelagem e simulação de sistemas. [dissertação]. Curitiba (PR): Pontifícia Universidade Católica do Paraná/ PUCPR; 2005.

12. Nepote MHA. Análise do desempenho das atividades no centro cirúrgico através de indicadores quantitativos e qualitativos. RAS. 2003;5(21):21-30.

13. Cologna MHYT, Dallora MELV, Hayashida M, Sawada NO. Análise da utilização de sala de cirurgia com apoio da informática. Rev. Latino-Am. Enfermagem. 1996;4 (n esp): 71-81.

14. Gatto MAF. Análise da utilização das salas de operações. [tese]. São Paulo (SP): Escola de Enfermagem de Ribeirão Preto da Universidade de São Paulo; 1995. 
15. Nepote MHA, Monteiro IU, Hardy E. Associação entre os índices operacionais e a taxa de ocupação de um centro cirúrgico geral. Rev. Latino-Am. Enfermagem. 2009;17(4):529-34. Inglês, Português, Espanhol.

16. Dexter $F$, Abouleish $A E$, Epstein $R H$, Whitten $C W$, Lubarsky DA: Use of operating room information system data to predict the impact of reducing turnover times on staffing costs. Anesth Analg. 2003;97:1119-26.

17. Macario A. Are your hospital operating rooms "efficient"? A scoring system with eight performance indicators. Anesthesiology. 2006 Aug;105(2):370-80.

18. Associação Médica Brasileira (AMB). Classificação Brasileira Hierarquizada de Procedimentos Médicos, 5.ed. 2008. [acesso 24 ago 2010]. Disponível em: http://www.amb.org.br/teste/cbhpm_5a.html.pdf.

19. Possari JF. Centro cirúrgico: planejamento, organização e gestão. São Paulo (SP): Iátria; 2004.

20. Kleinbaum DG, Klein M. Survival Analysis - a selflearning text. 2nd ed. New York: Springer; 2005.

21. Mello MC. Estudo do tempo no trabalho da enfermagem: construção de instrumento de classificação de atividades para implantação do método amostragem do trabalho [dissertação]. São Paulo: Escola de Enfermagem da Universidade de São Paulo; 2002.

22. Moreira DA. Medida da produtividade na empresa moderna. São Paulo: Pioneira; 1991.

23. Lage WM. Uma metodologia de custos de ociosidade em organizações hospitalares -necessidade, oportunidade e resultados. [acesso 10 jun 2010]. Disponível em http://www.intercostos.org/documentos/ Moreira\%20Lage.pdf.

24. Perroca MG, Jericó MC, Facundin SD. Surgery cancelling at a teaching hospital: implications for cost management. Rev. Latino-Am. Enfermagem. 2007;15(5):1018-24. Inglês, Português, Espanhol. 